\title{
Distribution uniformity in drip units applying dilutions of treated water produced by oil exploration
}

\author{
Hudson S. M. Vale ${ }^{1}$, Danniely O. Costa ${ }^{1}$, Rafael O. Batista ${ }^{2}$, Francisco de A. de Oliveira ${ }^{1}$, \\ José F. de Medeiros ${ }^{1} \&$ Daniela da C. L. Coelho ${ }^{2}$
}

${ }^{1}$ Universidade Federal Rural do Semi-Árido/Departamento de Ciências Agronômicas e Florestais, Mossoró, RN, Brasil. E-mail: klaus_angel@hotmail.com
- ORCID: 0000-0002-5391-117X; danniely_oliveira@hotmail.com - ORCID: 0000-0001-7966-9417; thikaoamigao@ufersa.edu.br - ORCID: 0000-0002-
6895-7736; jfmedeir@ufersa.edu.br - ORCID: 0000-0003-1202-8783
${ }^{2}$ Universidade Federal Rural do Semi-Árido/Departamento de Engenharia e Ciências Ambientais, Mossoró, RN, Brasil. E-mail: rafaelbatista@ufersa.edu.br
(Corresponding author) - ORCID: 0000-0002-3083-6808; daniela.coelho@ufersa.edu.br - ORCID: 0000-0001-9182-3675

\begin{abstract}
The objective of this study was to evaluate the uniformity of distribution in drip units applying dilutions of treated water produced by oil exploration. The experiment was set up in a completely randomized design in a split-split-plot scheme, with three replicates. The plots were composed of the treatments P0 - 100\% groundwater, control; P10 - 90\% groundwater and 10\% produced water; P20 - 80\% groundwater and $20 \%$ produced water; P30 - 70\% groundwater and 30\% produced water; and P40 - $60 \%$ groundwater and $40 \%$ produced water; the subplots had the types of non-pressure compensating drippers (D1 - $1.6 \mathrm{~L} \mathrm{~h}^{-1}$, Netafim Super Typhoon, D2 - 1.6 L h ${ }^{-1}$, Netafim Streamline and D3 - $1.7 \mathrm{~L} \mathrm{~h}^{-1}$, NaanDanJain TalDrip); and the sub-subplots contained the evaluation times $(0,40,80,120$ and $160 \mathrm{~h})$. Distribution uniformity and statistical uniformity coefficients were evaluated every $40 \mathrm{~h}$, until completing $160 \mathrm{~h}$. The $\mathrm{pH}$ of the dilutions was the attribute posing the highest risk of clogging to the emitters. Also in relation to dilutions, P40 caused greater application non-uniformity in D2, while the highest values of application uniformity were achieved in treatments P10 and P20 with D1 and D3, indicating the effectiveness of dilution in minimizing clogging.
\end{abstract}

Key words: irrigation efficiency, effluent, performance of drippers, clogging

\section{Uniformidade de distribuição em unidades gotejadoras aplicando diluições de água tratada produzida pela exploração do petróleo}

RESUMO: Objetivou-se, com este estudo, avaliar a uniformidade de distribuição em unidades gotejadoras aplicando diluições de água tratada produzida pela exploração do petróleo. O experimento foi montado no delineamento inteiramente casualizado em esquema de parcelas sub-subdivididas, com três repetições; tendo nas parcelas os tratamentos P0 - 100\% de água subterrânea, controle; P10 - 90\% de água subterrânea e 10\% de água produzida; P20 - 80\% de água subterrânea e 20\% de água produzida; P30 - 70\% de água subterrânea e 30\% de água produzida; e P40 - 60\% de água subterrânea e 40\% de água produzida; nas subparcelas os tipos de gotejadores não autocompensantes (D1 - 1,6 L h ${ }^{-1}$, Netafim Super Typhoon, D2 - 1,6 L h ${ }^{-1}$, Netafim Streamline e D3 - 1,7 L h ${ }^{-1}$, NaanDanJain TalDrip) e nas subsubparcelas os tempos de avaliação $(0,40,80$, 120 e 160 h). Foram avaliados os coeficientes de uniformidade de distribuição e de uniformidade estatístico a cada 40 h, até completar $160 \mathrm{~h}$. O pH das diluições foi o atributo que representou maior risco de obstrução aos emissores. Ainda em relação às diluições, P40 ocasionou maior desuniformidade de aplicação em D2, enquanto, os maiores valores de uniformidade de aplicação foram alcançados nos tratamentos P10 e P20 em D1 e D3, indicando eficácia da diluição na minimização da obstrução.

Palavras-chave: eficiência de irrigação, efluente, desempenho de gotejadores, obstrução 


\section{INTRODUCTION}

During the productive life of an oil field, there is simultaneous production of gas, oil and water (Haghshenas \& Nasr-El-Din, 2014). The water generated, commonly called produced water, is equivalent to $75 \%$ of the volume of extracted liquids (Munirasu et al., 2016).

The problem is that the produced water may contain high levels of organic and mineral compounds, as well as heavy metals (Al-Ghouti et al., 2019), which prevents its disposal in the environment, requiring adequate treatments to improve its quality. However, when properly treated, this water can become an alternative to irrigate crops whose products are not directly intended for human consumption (Weber et al., 2017). Thus, studies have been conducted to evaluate the effects of treated oil produced water in agricultural crops (Sousa et al., 2016; Meneses et al., 2017; Pica et al., 2017; Costa et al., 2019b).

Among the methods of irrigation, from an environmental point of view, localized irrigation is the most recommended for the disposal of wastewater in the environment, due to the high efficiency of application of the effluent and the low risk of contamination of the agricultural product and operators in the field (Rowan et al., 2013).

As a disadvantage, drip irrigation systems that operate with wastewater have high susceptibility to dripper clogging (Batista et al., 2008; Costa et al., 2019a).

The objective of this study was to evaluate the uniformity of effluent distribution in drip units, with three types of non-pressure compensating emitters, and supplied with five dilutions of treated oil produced water, during $160 \mathrm{~h}$.

\section{Material ANd Methods}

The present study was conducted from August 26 to October 5, 2018, in the experimental area of the Laboratório de Construções Rurais e Ambiência of the Departamento de Engenharia e Ciências Ambientais (DECAM) of the Centro de Engenharias (CE), located on the East Campus of the Universidade Federal Rural do Semi-Árido (UFERSA), in Mossoró, RN, Brazil (5²'13.14” S, 37²19'26.93” W and altitude of $18 \mathrm{~m}$ ).

The experiment was installed in a completely randomized design in a split-split-plot scheme, with three replicates. The plots contained five treatments (P0, P10, P20, P30 and $\mathrm{P} 40$ ), the subplots were composed of the three types of non-pressure compensating drippers (D1 - 1.6 $\mathrm{L} \mathrm{h}^{-1}$, D2 - 1.6 $\mathrm{L} \mathrm{h}^{-1}$ and D3 - 1.7 $\mathrm{L} \mathrm{h}^{-1}$ ), and the sub-subplots had the times of evaluation $(0,40,80,120$ and $160 \mathrm{~h})$ of the effluent distribution uniformity.

Five experimental benches of $8.00 \mathrm{~m}^{2}$ ( $1.00 \mathrm{~m}$ wide by 8.00 $\mathrm{m}$ long), consisting of a wooden base to support corrugated fiber-cement roofing sheets, were set up in this area. The roofing sheets were installed with $2.50 \%$ slope to enable the recirculation of the effluent. Downstream of each bench, a $0.31 \mathrm{~m}^{3}$ reservoir was installed coupled to a drip irrigation system composed of a 0.50 -hp motor-pump set, a screen filter with $130-\mu \mathrm{m}$ openings, a gate valve, a point for collecting effluent samples, an analog glycerin manometer (graduated from 0 to $400 \mathrm{kPa}$ ), a $32-\mathrm{mm}$-diameter main line, a 50-mmdiameter sub-main line and nine 8 -m-long lateral lines. Figure 1 shows a sketch of the experimental area.

On each experimental bench, a drip irrigation system was setup, divided into three drip subunits, in a completely randomized distribution. Each drip subunit consisted of three lateral lines of the same emitter manufacturer.

The three emitters evaluated are labyrinth-type, nonpressure compensating and were selected based on the lower susceptibility to clogging and because they are widely commercialized in the national market (Table 1).

The dilutions were performed with graduated buckets and stored in the downstream reservoirs of each bench, corresponding to each treatment, which were based on the results found by Costa (2018), who found that the treatment with $75 \%$ of supply water and $25 \%$ of the treated produced water had the best effects on sunflower irrigation. Thus, the following treatments were evaluated:

a) P0 - $100 \% \mathrm{GW}$ (groundwater), control;

b) P10 - 90\% GW and 10\% PW (treated produced water);

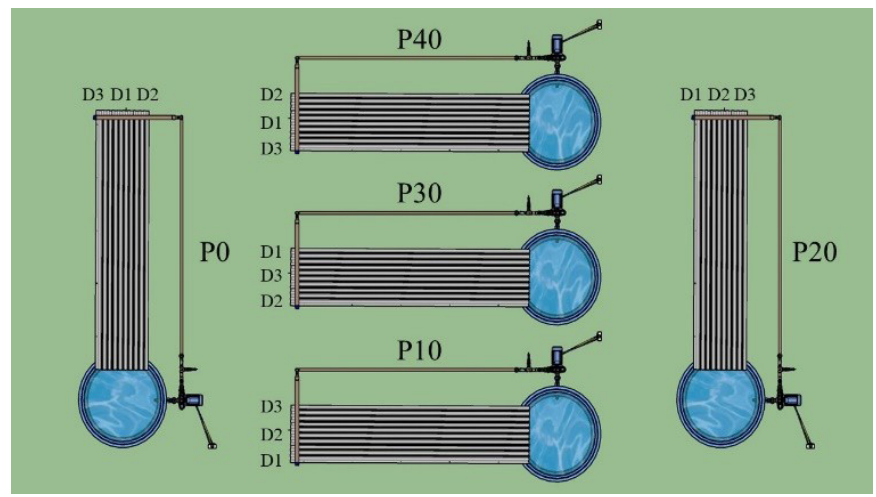

P0 - 100\% groundwater (GW); P10 - 90\% GW and 10\% treated produced water (PW); P20 - 80\% GW and 20\% PW; P30 - 70\% GW and 30\% PW; P40 - 60\% GW and 40\% PW; Drippers: D1 - 1.6 $\mathrm{L} \mathrm{h}^{-1}$, D2 - 1.6 $\mathrm{L} \mathrm{h}^{-1}$ and D3 - $1.7 \mathrm{~L} \mathrm{~h}^{-1}$

Figure 1. Sketch of experimental plots for applying the treatments via drip irrigation system

Table 1. Technical specifications extracted from manufacturers' catalogues and images of the non-pressure compensating drippers used in the study

\begin{tabular}{|c|c|c|c|c|c|c|c|c|c|}
\hline Manufacturer & $\begin{array}{c}\mathbf{a} \\
\left(L^{-1}\right)\end{array}$ & k & $x$ & $\underset{\left(\mathrm{mm}^{2}\right)}{\mathrm{A}}$ & $\underset{(\mathrm{mm})}{\mathrm{L}}$ & $\begin{array}{l}\text { CVm } \\
(\%)\end{array}$ & $\begin{array}{c}P \\
(\mathrm{kPa})\end{array}$ & $\begin{array}{l}\text { SE } \\
(m)\end{array}$ & Images of drippers \\
\hline Netafim Super Typhoon - D1 & 1.60 & 0.53 & 0.48 & 34.0 & 23 & \pm 7 & $60-100$ & 0.30 & 8il|||이 \\
\hline Netafim Streamline - D2 & 1.60 & 0.57 & 0.45 & 17.0 & 13 & \pm 7 & $65-100$ & 0.30 & 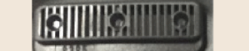 \\
\hline NaanDanJain TalDrip - D3 & 1.70 & 0.56 & 0.46 & $6.0^{\mathrm{a}}$ & $44^{a}$ & \pm 5 & $50-300$ & 0.20 & 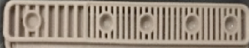 \\
\hline
\end{tabular}

Q - Nominal flow rate; $\mathrm{k}$ - Coefficient of flow rate equation; $\mathrm{x}$ - Exponent of the flow rate equation that characterizes the flow regime; A - Filtration area; $\mathrm{L}$ - Labyrinth length; $\mathrm{CVm}$ - Coefficient of variation of manufacturing; P - Recommended pressure range and SE - Spacing between emitters; ${ }^{\mathrm{a}}$ Information obtained using a digital caliper with $0.01 \mathrm{~mm}$ accuracy 
c) P20 - 80\% GW and $20 \% \mathrm{PW}$;

d) P30 - 70\% GW and 30\% PW; and,

e) P40 - 60\% GW and 40\% PW.

The treated produced water (PW) came from a company that exploits oil in the Potiguar Basin, near the municipality of Jucuri, RN, rural area of the municipality of Mossoró, Brazil. After collection, this water was treated at the site of the experiment with the organic polymer AGEFLOC DW-3753, whereas the groundwater (GW) came from a tubular well managed by Companhia de Águas e Esgotos do Rio Grande do Norte (CAERN).

The drip subunits of each bench worked on average $4 \mathrm{~h}$ per day, until completing the operating time of $160 \mathrm{~h}$, to enhance the formation of fouling in the drippers and lateral lines. Along this period, five evaluations of effluent distribution uniformity were performed every $40 \mathrm{~h}$, specifically at the operating times of $0,40,80,120$ and $160 \mathrm{~h}$.

For this, flow rate was determined in 16 emitters selected per lateral line, as recommended by Capra \& Scicolone (1998), totaling 48 emitters per drip subunit. Then, the volume of effluent applied was collected by the emitter for $3 \mathrm{~min}$.

After tabulating the flow rate data, the hydraulic performance of the drip subunits operating with dilutions was determined based on the distribution uniformity coefficient (DUC) and the statistical uniformity coefficient (Us).

$$
\begin{gathered}
\mathrm{DUC}=100 \frac{\mathrm{q}_{25 \%}}{\overline{\mathrm{q}}} \\
\mathrm{Us}=100\left(1-\frac{\mathrm{S}_{\mathrm{n}}}{\overline{\mathrm{q}}}\right)
\end{gathered}
$$

where:

DUC - distribution uniformity coefficient, \%;

$\mathrm{q}_{25 \%}$ - average value of the $25 \%$ lowest flow rates of the drippers, $\mathrm{L} \mathrm{h}^{-1}$;

q - average flow rate of the drippers, $\mathrm{L} \mathrm{h}^{-1}$;

Us - statistical uniformity coefficient of effluent application, \%; and, $\mathrm{L} \mathrm{h}^{-1}$.

$\mathrm{S}_{\mathrm{n}} \quad$ - standard deviation of the flow rate of the drippers,

The physico-chemical characteristics of the dilutions of PW in GW were determined every $40 \mathrm{~h}$ until they completed $160 \mathrm{~h}$ of operation in the drip units. At the Laboratório de
Análise de Solo, Água e Planta (LASAP) of UFERSA, hydrogen potential $(\mathrm{pH})$ was measured with a potentiometer, electrical conductivity (EC) through a conductivity meter, and calcium $\left(\mathrm{Ca}^{2+}\right)$ and magnesium $\left(\mathrm{Mg}^{2+}\right)$ by the titrimetric method. The concentrations of total suspended solids (TSS) were determined by the gravimetric method, while the concentrations of total dissolved solids (TDS) were obtained by difference between the concentrations of total solids and TSS.

The data of the uniformity of application of dilutions were subjected to analysis of variance at $\mathrm{p} \leq 0.01$ by $\mathrm{F}$ test. Regression models, as a function of the time of operation of the drip subunits, were selected based on the coefficient of determination $\left(R^{2} \geq 0.80\right)$, on the significance of the regression coefficients, applying the $\mathrm{t}$-test at $\mathrm{p} \leq 0.10$, and on the process in study.

\section{RESULTS ADISCUSSION}

Table 2 shows the mean values and standard deviations of the physico-chemical characteristics of the dilutions of PW in GW, as well as the standard values related to the risk of dripper clogging.

Regarding $\mathrm{pH}$, the risk of dripper clogging was considered severe for all dilutions, because the mean values were higher than the limit of 7.5 established by Nakayama et al. (2006). This result is similar to those obtained by Silva et al. (2017), who also stated that the $\mathrm{pH}$ of irrigation water represented a serious risk of dripper clogging.

In relation to $\mathrm{EC}$, the risk of clogging was considered low for this attribute, because its mean values were lower than the limit of $1.0 \mathrm{dS} \mathrm{m^{-1 }}$ established by Capra \& Scicolone (1998). This result differs from that reported by Fernandes et al. (2014), who found that the risk of clogging for EC was classified as severe, along the entire experimental period.

The mean concentrations of $\mathrm{Ca}^{2+}$ and $\mathrm{Mg}^{2+}$ were lower than the limits of 12.5 and $2.0 \mathrm{mmol}_{\mathrm{c}} \mathrm{L}^{-1}$, respectively, established by Capra \& Scicolone (1998), representing a low risk of dripper clogging. Similarly, Fernandes et al. (2017) also classified the risk of clogging for $\mathrm{Ca}^{2+}$ and $\mathrm{Mg}^{2+}$ as low in drippers that operated with dilutions of treated domestic wastewater.

With regard to TSS and TDS, their concentrations were also lower than the limits of 50 and $500 \mathrm{mg} \mathrm{L}^{-1}$, respectively, established by Nakayama et al. (2006), so the risk of emitter clogging was classified as low. When evaluating the clogging of drippers operating with diluted dairy effluent, Cunha et al. (2017) classified the risk of clogging as severe for TSS and

Table 2. Mean values and standard deviations of the physico-chemical characteristics of the diluted treated produced water,

\begin{tabular}{|c|c|c|c|c|c|c|c|c|}
\hline \multirow{2}{*}{ Attributes } & \multicolumn{7}{|c|}{ Means and standard deviations } & \multirow{2}{*}{$\begin{array}{c}\text { Risk } \\
\text { of clogging }\end{array}$} \\
\hline & PO & P10 & P20 & & P30 & & P40 & \\
\hline $\mathrm{pH}$ & $8.70 \pm 0.27$ & $8.57 \pm 0.20$ & $8.61 \pm 0.23$ & 8.47 & \pm & 0.16 & $8.60 \pm 0.05$ & Severe ${ }^{\mathrm{a}}$ \\
\hline EC & $0.72 \pm 0.08$ & $0.75 \pm 0.16$ & $0.78 \pm 0.12$ & 0.72 & \pm & 0.06 & $0.63 \pm 0.07$ & Low $^{b}$ \\
\hline $\mathrm{Ca}^{2+}$ & $0.50 \pm 0.27$ & $0.68 \pm 0.30$ & $0.86 \pm 0.45$ & 1.07 & \pm & 0.55 & $1.05 \pm 0.94$ & Low $^{b}$ \\
\hline $\mathrm{Mg}^{2+}$ & $0.38 \pm 0.13$ & $0.51 \pm 0.24$ & $0.74 \pm 0.25$ & 0.65 & $\overline{ \pm}$ & 0.51 & $1.00 \pm 0.61$ & Low $^{b}$ \\
\hline TSS & $10.00 \pm 5.55$ & $10.00 \pm 4.69$ & $8.00 \pm 2.28$ & 12.00 & \pm & 5.59 & $8.00 \pm 4.90$ & Lowa $^{a}$ \\
\hline TDS & $298.00 \pm 122.49$ & $372.50 \pm 97.12$ & $379.00 \pm 75.13$ & 318.50 & \pm & 129.11 & $318.50 \pm 129.04$ & Low $^{\mathrm{a}}$ \\
\hline
\end{tabular}
compared to the patterns related to the risk of dripper clogging

P0 - 100\% groundwater, control; P10 - 90\% groundwater and 10\% produced water; P20 - 80\% groundwater and $20 \%$ produced water; P30 - $70 \%$ groundwater and $30 \%$ produced water; and P40 - 60\% groundwater and 40\% produced water; $\mathrm{pH}$ - Hydrogen potential; EC - Electrical conductivity, $\mathrm{dS} \mathrm{m}^{-1} ; \mathrm{Ca}^{2+}-\mathrm{Calcium}^{2} \mathrm{mmol}_{\mathrm{c}} \mathrm{L}^{-1} ; \mathrm{Mg}^{2+}-\mathrm{Magnesium}_{\mathrm{m}} \mathrm{mmol}_{\mathrm{c}}$ $\mathrm{L}^{-1}$; TSS - Total suspended solids, $\mathrm{mg} \mathrm{L}^{-1}$ and TDS - Total dissolved solids, $\mathrm{mg} \mathrm{L}^{-1} ;^{\mathrm{a}}$ Nakayama et al. (2006); ${ }^{\mathrm{b}}$ Capra \& Scicolone (1998). 
moderate for TDS, which differs from the results found in the present study.

Table 3 presents the mean values of the distribution uniformity coefficient (DUC) and statistical uniformity coefficient (Us) of the drip subunits with the emitters D1, D2 and D3, subjected to treatments P0, P10, P20, P30 and P40, along the operating time.

For the dripper D1, when comparing the initial $(0 \mathrm{~h})$ and final $(160 \mathrm{~h})$ operation times, it was found that the reductions in DUC values were 2.20 and $21.05 \%$ for the treatments P10 and $\mathrm{P} 40$, respectively, while for $\mathrm{P} 0$ there was an increase in DUC of the order of $5.49 \%$. The mean values of DUC remained constant for the treatments P20 and P30.

For the dripper D2, there were reductions in the DUC values of $4.60,5.43,21.51$ and $72.92 \%$ in the subunits subjected to the treatments P0, P20, P30 and P40, respectively, between the operating times of 0 and $160 \mathrm{~h}$. These reductions can be attributed to the partial clogging of the dripper, caused by the formation of fouling over time, compromising the effluent application uniformity. Differently, for the subunit subjected to the treatment $\mathrm{P} 10$ there was a slight increase of $1.10 \%$.

In relation to the dripper D3, between the initial and final operation times $(160 \mathrm{~h})$, there were reductions in the mean values of DUC for the subunits subjected to the treatments P20, P30 and P40, which were equal to $3.16,10.87$ and 9.78\%, respectively. For the treatments $\mathrm{P} 0$ and $\mathrm{P} 10$, the DUC values remained constant.

Batista et al. (2013) noticed reductions in DUC values of up to $87 \%$, which was observed for the dripper D1 $\left(2.00 \mathrm{~L} \mathrm{~h}^{-1}\right)$ in the subunit subjected to $2 \mathrm{E} 2 \mathrm{~A}$ management (two hours of application of swine wastewater followed by two hours of application of supply water). A study conducted by PuigBargués et al. (2010) with treated wastewater found that the DUC decreased from $95.1 \%$ to $76.0 \%$, after $1620 \mathrm{~h}$ of operation of the drip irrigation units.

For the dripper D1, between the initial $(0 \mathrm{~h})$ and final $(160 \mathrm{~h})$ operating times, there were reductions in Us values of 1.06 and $19.79 \%$ for the subunits subjected to the treatments P10 and P40, respectively. On the other hand, for the subunit subjected to $\mathrm{P} 0$ there was an increase of around $3.23 \%$. The mean Us values remained constant for the treatments P20 and P30.

For the dripper D2, when comparing the operating times of 0 and $160 \mathrm{~h}$, it was found that the mean Us values of the subunits subjected to the treatments P0, P20, P30 and P40 decreased by $6.59,6.45,17.89$ and $46.88 \%$, respectively. For the subunit subjected to P10, there was an increase in Us of the order of $1.08 \%$.

The dripper D3 showed reductions in its mean values between the initial and final operation times in the subunits subjected to the treatments P0 (1.05\%), P20 (2.08\%), P30

Table 3. Mean values of the distribution uniformity coefficient (DUC) and statistical uniformity coefficient (Us) of the drip subunits with the emitters D1, D2 and D3, applying dilutions of treated oil produced water along the operating time

\begin{tabular}{|c|c|c|c|c|c|c|}
\hline \multirow{2}{*}{ Dripper } & \multirow{2}{*}{ Treatment } & \multicolumn{5}{|c|}{ Time (hours) } \\
\hline & & 0 & 40 & 80 & 120 & 160 \\
\hline \multicolumn{7}{|c|}{ DUC $^{a}(\%)$} \\
\hline \multirow{5}{*}{ D1 } & PO & 91 (excellent) & 93 (excellent) & 94 (excellent) & 94 (excellent) & 96 (excellent) \\
\hline & P10 & 93(excellent) & 92 (excellent) & 92 (excellent) & 89 (good) & 91 (excellent) \\
\hline & P20 & 96 (excellent) & 96 (excellent) & 94 (excellent) & 95 (excellent) & 96 (excellent) \\
\hline & P30 & 94 (excellent) & 91 (excellent) & 93 (excellent) & 93 (excellent) & 94 (excellent) \\
\hline & P40 & 95 (excellent) & 90 (excellent) & 94 (excellent) & 80 (good) & 75 (regular) \\
\hline \multirow{5}{*}{$\mathrm{D} 2$} & $\mathrm{PO}$ & 87 (good) & 88 (good) & 89 (good) & 88 (good) & 83 (good) \\
\hline & P10 & 91 (excellent) & 93 (excellent) & 93 (excellent) & 95 (excellent) & 92 (excellent) \\
\hline & P20 & 92 (excellent) & 93 (excellent) & 82 (good) & 90 (good) & 87 (good) \\
\hline & P30 & 93 (excellent) & 93 (excellent) & 90 (good) & 79 (regular) & 73 (regular) \\
\hline & P40 & 96 (excellent) & 88 (good) & 78 (regular) & 56 (poor) & 26 (poor) \\
\hline \multirow{5}{*}{ D3 } & PO & 94 (excellent) & 93 (excellent) & 93 (excellent) & 97 (excellent) & 94 (excellent) \\
\hline & P10 & 95 (excellent) & 96 (excellent) & 93 (excellent) & 96 (excellent) & 95 (excellent) \\
\hline & P20 & 95 (excellent) & 93 (excellent) & 94 (excellent) & 91 (excellent) & 92 (excellent) \\
\hline & P30 & 92 (excellent) & 89 (good) & 88 (good) & 87 (good) & 82 (good) \\
\hline & P40 & 92 (excellent) & 95 (excellent) & 95 (excellent) & 90 (good) & 83 (good) \\
\hline \multicolumn{7}{|c|}{$U s^{\mathrm{b}}(\%)$} \\
\hline \multirow{5}{*}{ D1 } & PO & 93 (excellent) & 95 (excellent) & 95 (excellent) & 95 (excellent) & 96 (excellent) \\
\hline & P10 & 94 (excellent) & 93 (excellent) & 94 (excellent) & 92 (excellent) & 93 (excellent) \\
\hline & P20 & 97 (excellent) & 97 (excellent) & 96 (excellent) & 96 (excellent) & 97 (excellent) \\
\hline & P30 & 95 (excellent) & 93 (excellent) & 94 (excellent) & 94 (excellent) & 95 (excellent) \\
\hline & P40 & 96 (excellent) & 92 (excellent) & 95 (excellent) & 82 (good) & 77 (reasonable) \\
\hline \multirow{5}{*}{$\mathrm{D} 2$} & PO & 91 (excellent) & 90 (good) & 92 (excellent) & 90 (good) & 85 (good) \\
\hline & P10 & 93 (excellent) & 94 (excellent) & 94 (excellent) & 96 (excellent) & 94 (excellent) \\
\hline & P20 & 93 (excellent) & 94 (excellent) & 84 (good) & 92 (excellent) & 87 (good) \\
\hline & P30 & 95 (excellent) & 94 (excellent) & 92 (excellent) & 82 (good) & 78 (reasonable) \\
\hline & P40 & 96 (excellent) & 90 (good) & 81 (good) & 68 (poor) & 51 (unacceptable) \\
\hline \multirow{5}{*}{ D3 } & PO & 95 (excellent) & 95 (excellent) & 94 (excellent) & 97 (excellent) & 94 (excellent) \\
\hline & P10 & 96 (excellent) & 97 (excellent) & 94 (excellent) & 97 (excellent) & 96 (excellent) \\
\hline & P20 & 96 (excellent) & 95 (excellent) & 95 (excellent) & 94 (excellent) & 94 (excellent) \\
\hline & P30 & 93 (excellent) & 91 (excellent) & 91 (excellent) & 90 (excellent) & 86 (good) \\
\hline & P40 & 94 (excellent) & 96 (excellent) & 96 (excellent) & 92 (excellent) & 86 (good) \\
\hline
\end{tabular}

P0 - 100\% groundwater (GW), P10 - 90\% GW and 10\% treated produced water (PW), P20 - 80\% GW and 20\% PW, P30 - 70\% GW and 30\% PW and P40 - 60\% GW and 40\% PW

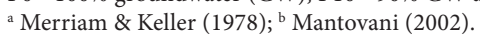


(7.53\%) and P40 (8.51\%). Differently, the value of Us remained constant for the treatment P10.

Batista et al. (2011) found average Us reductions of 54, 24 and $59 \%$ in drip irrigation systems applying primary, secondary and tertiary domestic wastewater, respectively, after $500 \mathrm{~h}$ of operation.

Hydraulic performance results indicated that the dripper D2, subjected to the treatment P40, had higher level of nonuniformity of water application than D1 and D3, probably due to its smaller filtration area (when compared to D1, under the same recommended pressure range, as shown in Table 1), and to the formation of fouling on it, which made it difficult for the effluent to enter through the small openings, thus causing a reduction in the flow rate along the lateral lines and, consequently, changing the application uniformity of the system. Similar behavior was observed by Batista et al. (2017), when analyzing the clogging dynamics of three dripper models (distinct from those of the present study), operating with swine wastewater.

A.

D1P0

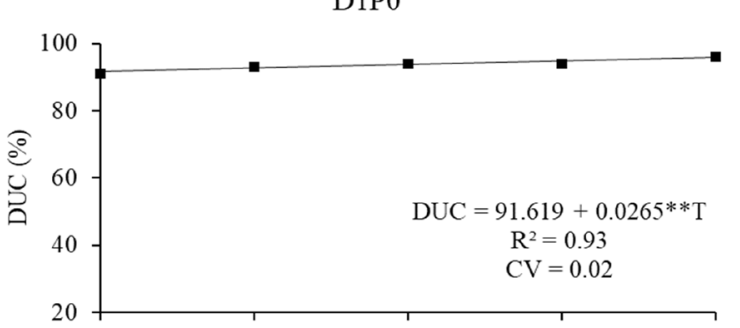

C.

D1P30

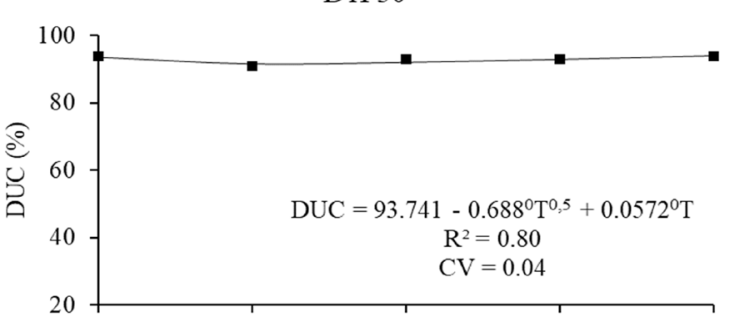

E.

D3P30

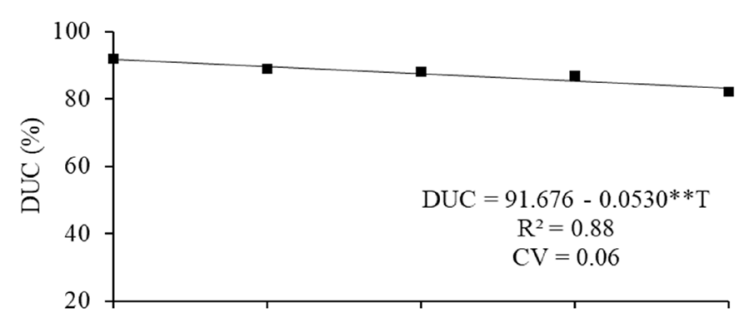

G.

$\mathrm{D} 2 \mathrm{P} 40$

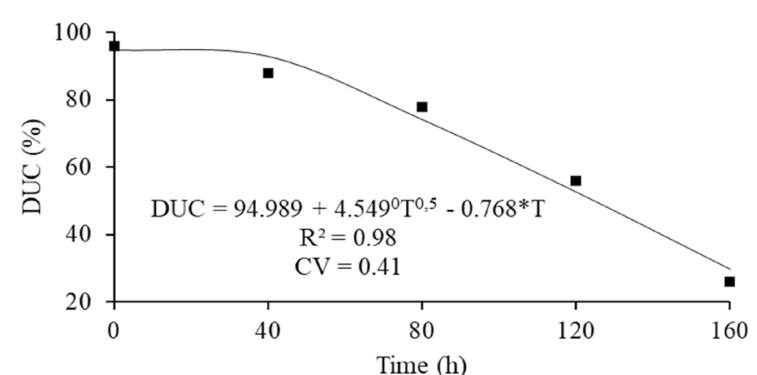

In addition, the higher non-uniformity of water application in the dripper D2 may be associated in part with the shorter length of the labyrinth. These authors concluded that the dripper with smaller labyrinth and lower flow rate showed higher susceptibility to clogging.

Figure 2 shows the significant regression equations fitted to the distribution uniformity coefficient (DUC) as a function of the operating times $(\mathrm{T})$ of the drip subunits for the three types of drippers (D1, D2 and D3) and the five treatments evaluated (P0, P10, P20, P30 and P40).

It was observed that, after $160 \mathrm{~h}$ of operation of the system, the highest DUC value (95.86\%) was found for the dripper D1 subjected to the treatment P0 (Figure 2A), while the lowest value $(29.65 \%)$ occurred for the dripper D2 subjected to the treatment P40, according to Figure $2 \mathrm{G}$.

The oscillations in the DUC values, along the time of operation of the system, may have occurred because of the spontaneous unclogging due to the increase in temperature

B.

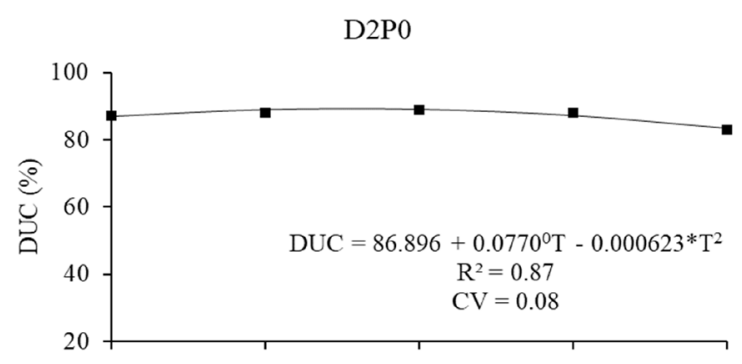

D.

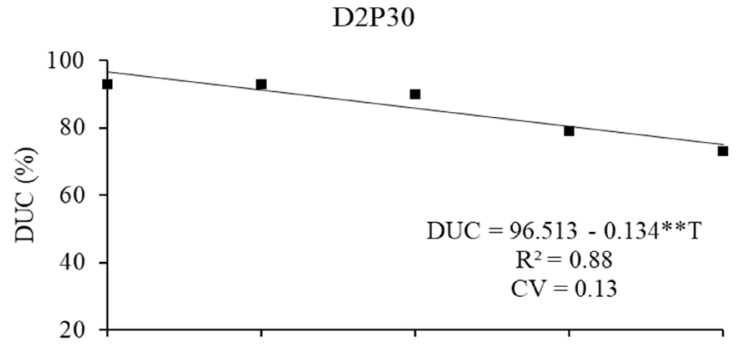

F.

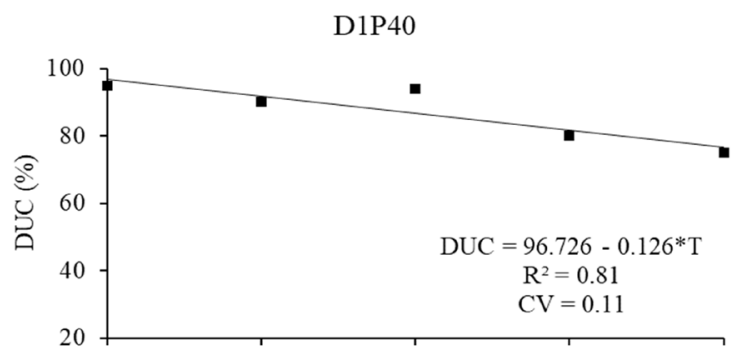

H.

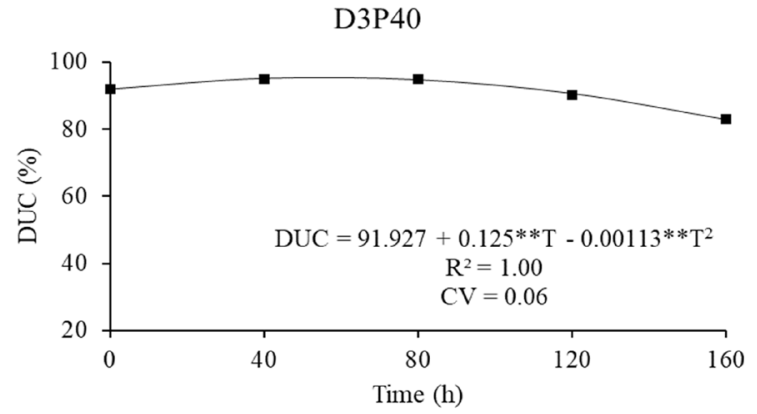

P0 - 100\% of groundwater, control; P10 - 90\% of groundwater and $10 \%$ of produced water; P20 - $80 \%$ of groundwater and $20 \%$ of produced water; P 30 - $70 \%$ of groundwater and $30 \%$ of produced water; and P40 - 60\% of groundwater and 40\% of produced water; in the subplots the types of non-pressure compensating drippers (D1 - $1.6 \mathrm{~L} \mathrm{~h}^{-1}$, Netafim Super Typhoon, D2 - 1.6 L h ${ }^{-1}$, Netafim Streamline and D3 - $1.7 \mathrm{~L} \mathrm{~h}^{-1}$, NaanDanJain TalDrip); ${ }^{* *},{ }^{*}$ and ${ }^{0}$ Significant at $\mathrm{p} \leq 0.01, \mathrm{p} \leq 0.05$ and $\mathrm{p} \leq 0.10$, respectively, by t-test; CV - Coefficient of variation Figure 2. Significant regression equations fitted to the DUC variable as a function of the operating times (T) of the irrigation subunits for the three types of drippers (D1, D2 and D3) and the five treatments evaluated (P0, P10, P20, P30 and P40) 
during a certain period, causing the fouling to detach from the labyrinth walls.

It was found that the square root model expressed better the relationship between the DUC and T data for the dripper D1 subjected to P30 and for the dripper D2 subjected to P40. Similarly, Vale et al. (2018) reported that the square root regression model fitted better to DUC data and to the operating time in the irrigation subunit with dripper D2, operating with diluted landfill leachate, under operating pressure of $210 \mathrm{kPa}$, for $160 \mathrm{~h}$.

On the other hand, the quadratic model fitted better to the DUC values, as a function of $\mathrm{T}$, for the dripper $\mathrm{D} 2$ subjected to $\mathrm{P} 0$ and for the dripper D3 subjected to P40.

There was a linear relationship between DUC and T for the dripper D1 subjected to the treatments $\mathrm{P} 0$ and P40 and for the drippers D2 and D3 subjected to P30.

For the other combinations between types of drippers and treatments, there was no significant effect of the time of

A.

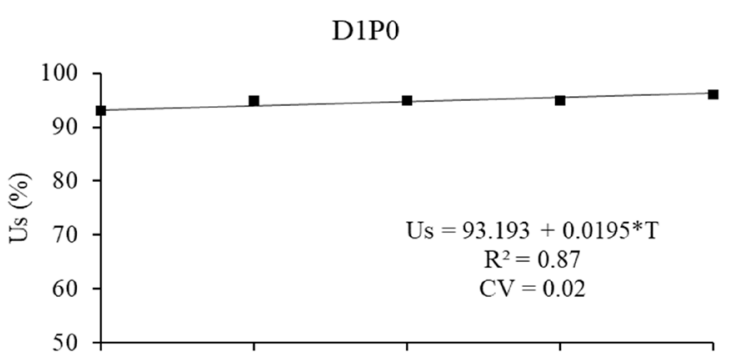

C.

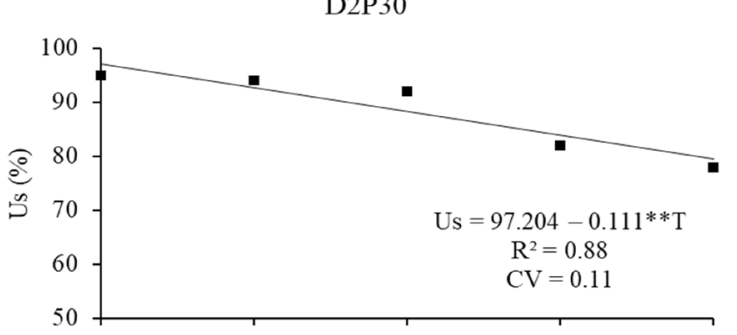

E.

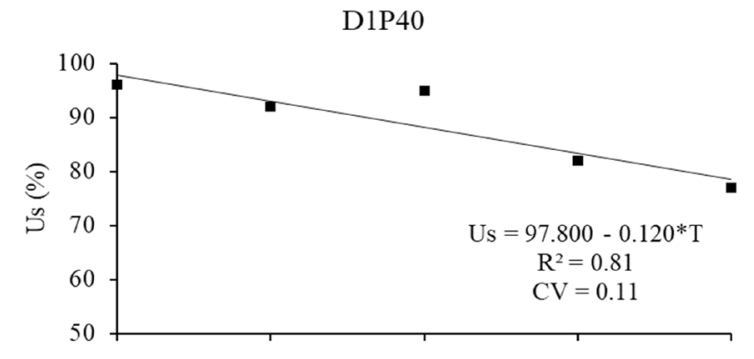

operation (T) on DUC data, indicating that the mean was the best representation.

Working with cashew nut wastewater, Silva et al. (2016) mentioned that the linear regression and square root models fitted to $17 \%$ of the combinations, each, between three dripper models and four operating pressures, while the mean was the best representation for the other combinations, indicating greater resistance to clogging.

Figure 3 shows the significant regression equations fitted to the statistical uniformity coefficient (Us) as a function of the operating times $(\mathrm{T})$ of the drip subunits for the three types of emitters (D1, D2 and D3) and the five treatments evaluated (P0, P10, P20, P30 and P40).

This figure showed that, after $160 \mathrm{~h}$ of operation of the system, the highest value (96.31\%) of Us was observed for the dripper D1 subjected to P0 (Figure 3A), whereas the lowest value (54.81\%) occurred for the dripper D2 subjected to P40 (Figure 3F).

B.

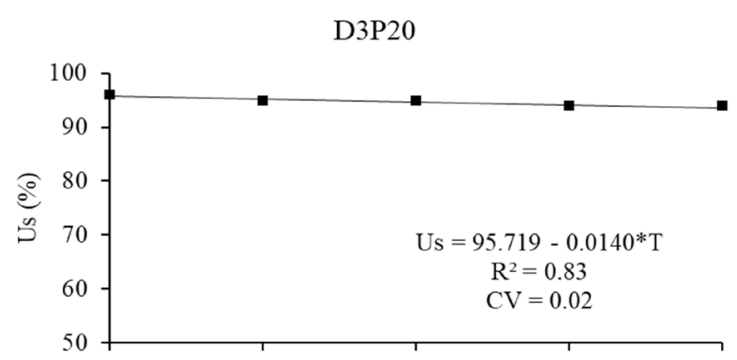

D.

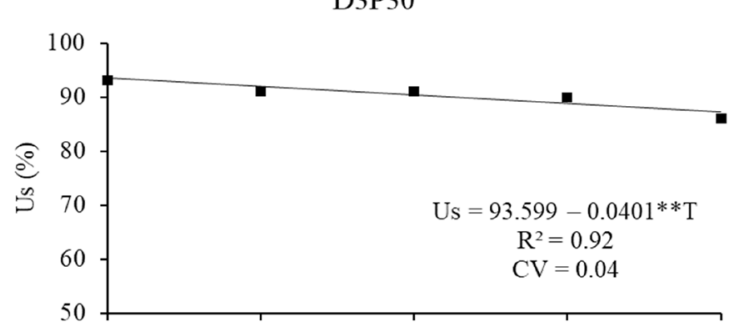

F.

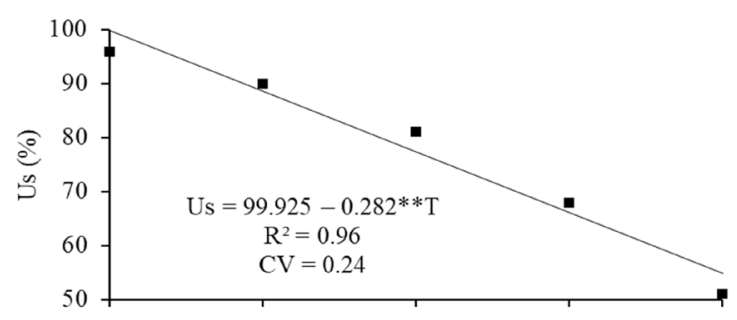

G.

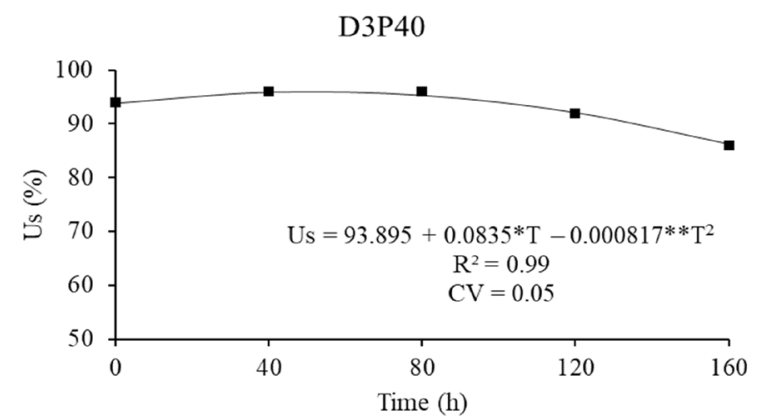

In the subplots the types of non-pressure compensating drippers (D1 - 1.6 L h ${ }^{-1}$, Netafim Super Typhoon, D2 - 1.6 L h ${ }^{-1}$, Netafim Streamline and D3 - 1.7 L h ${ }^{-1}$, NaanDanJain TalDrip); ${ }^{*},{ }^{* *}$ - Significant at $\mathrm{p} \leq 0.05$ and $\mathrm{p} \leq 0.01$, respectively, by t-test ; CV - Coefficient of variation

Figure 3. Significant regression equations fitted to the Us variable as a function of the operating times (T) of the irrigation subunits for the three types of drippers (D1, D2 and D3) and the five treatments evaluated (P0, P10, P20, P30 and P40) 
The linear regression model was the one that best fitted to the relationship between Us and T data for the dripper D1 subjected to the treatments $\mathrm{P} 0$ and $\mathrm{P} 40$, for the dripper $\mathrm{D} 2$ subjected to P30 and P40 and for the dripper D3 subjected to P20 and P30.

For the dripper D3 subjected to the treatment P40, the regression model that best fitted was quadratic. There was no significant effect of the time of operation (T) on the Us values for the other combinations between types of drippers and treatments, with the mean being the best representation of the data.

Batista et al. (2016) found that the linear, square root and quadratic regression models fitted better to the relationship between Us data and the time of operation for drip irrigation subunits with three types of emitters, operating with swine wastewater under operating pressures of 70, 140, 210 and 280 $\mathrm{kPa}$, for $160 \mathrm{~h}$.

\section{Conclusions}

1. Among the physico-chemical characteristics of the dilutions of treated produced water, only $\mathrm{pH}$ represented a severe risk of dripper clogging, while the attributes electrical conductivity, calcium, magnesium, total suspended solids and total dissolved solids represented low risk of clogging.

2. The highest levels of non-uniformity in the application of the dilutions occurred in the drip unit with Netafim StreamLine emitter when subjected to the treatment P40 (60\% of groundwater plus $40 \%$ of treated water produced by oil exploration).

3. Regarding the coefficients of uniformity of application of the dilutions, the highest levels along the experimental period occurred in the treatments P10 (90\% groundwater plus $10 \%$ of treated oil produced water) and P20 (80\% groundwater plus $20 \%$ of treated oil produced water) in the drip units with the drippers Netafim Super Typhoon and NaanDanJain TalDrip.

\section{ACKNOWLeDgments}

The present study was carried out with support from Coordenação de Aperfeiçoamento de Pessoal de Nível Superior - Brazil (CAPES) - Financing Code 001, Financiadora de Estudos e Projetos (FINEP) through the BRAMAR Project and Conselho Nacional de Desenvolvimento Científico e Tecnológico (CNPq).

\section{Literature Cited}

Al-Ghouti, M. A.; Al-Kaabi, M. A.; Ashfaq, M. Y.; Da’na; D. A. Produced water characteristics, treatment and reuse: A review. Journal of Water Process Engineering, v.28, p.222-239, 2019. https://doi.org/10.1016/j.jwpe.2019.02.001

Batista, R. O.; Costa, F. G. B.; Lopes, H. S. S.; Coelho, D. C. L.; Costa Paiva, M. R. F. Efeito das características do esgoto doméstico na uniformidade de aplicação de sistemas de irrigação por gotejamento. Revista Caatinga, v.24, p.137-144, 2011.

Batista, R. O.; Ferreira, D. de J. L.; Santos, D. B. dos; Lemos Filho, L. C. de A; Rocha, T. A. L. C. G.; Medeiros, I. E. S. Vazão de gotejadores ao longo de linhas laterais operando com água residuária da suinocultura sob pressões de serviço. Revista Espacios, v.38, p.7-17, 2017.
Batista, R. O.; Oliveira, R. A. de; Santos, D. B. dos; Cunha, F. F. da; Medeiros, S. de S. Modelos empíricos da aplicação de água residuária de suinocultura por gotejadores sob pressões de serviço. Irriga, v.21, p.648-661, 2016. https://doi.org/10.15809/ irriga.2016v21n4p648-661

Batista, R. O.; Oliveira, R. A.; Santos, D. B.; Oliveira, A. F. M.; Azevedo, C. A. V.; Medeiros, S. S. Obstrução e uniformidade de aplicação em sistemas de irrigação por gotejamento aplicandose efluente da suinocultura. Revista Brasileira de Engenharia Agrícola e Ambiental, v.17, p.698-705, 2013. https://doi. org/10.1590/S1415-43662013000700002

Batista, R. O.; Soares, A. A.; Souza, J. A. R. de; Batista, R. O. Modelos empíricos da irrigação localizada com esgoto sanitário tratado. Engenharia na Agricultura, v. 16, p.369-377, 2008. https://doi. org/10.13083/1414-3984.v16n03a12

Capra, A.; Scicolone, B. Water quality and distribution uniformity in drip/trickle irrigation systems. Journal of Agricultural Engineering Research, v.70, p.355-365, 1998. https://doi. org/10.1006/jaer.1998.0287

Costa, D. O.; Vale, H. S. M.; Batista, R.O.; Silva, P. C. M.; Lemos Filho, L. C. A.; Santos, D. B. Suscetibilidade ao entupimento de gotejadores aplicando água residuária doméstica tratada. RAMA - Revista em Agronegócio e Meio Ambiente, v. 12, p. 1251-1266, 2019a. https://doi.org/10.17765/21769168.2019v12n4p1251-1266

Costa, D. O.; Vale, H. S. M.; Batista, R. O.; Travassos, K. D.; Portela, J. C. Chemical characteristics of soil irrigated with produced water treatment and underground water. Dyna, v. 86, p. 143-149, 2019b. https://doi.org/10.15446/dyna.v86n210.79115

Costa, F. G. B. Produção e capacidade de fitoextração do girassol (Heliantus annus) irrigado com água produzida. 93p. UFERSA: Mossoró. 2018. Tese Doutorado

Cunha, M. E.; Marques, B. C. D.; Batista, R. O.; Costa, A. G.; Cunha, R. R.; Andrade, A. T. S. Obstrução de gotejadores operando com efluente de laticínios diluído. Revista Brasileira de Agricultura Irrigada, v.11, p.1517-1527, 2017. https://doi.org/10.7127/rbai. v11n400644

Fernandes, F. G. B. C.; Batista, R. O.; Ferreira, D. J. L.; Silva, S. L.; Pereira, J. P.; Cunha, J. L. O. Desempenho de sistema de irrigação por gotejamento operando com diluições de água residuária doméstica tratada. Revista Espacios, v.38, p.10, 2017.

Fernandes, R. K. A.; Batista, R. O.; Silva, S. K. C.; Oliveira, J. F.; Paiva, L. A. L. Vazão de gotejadores aplicando água residuária da castanha de caju. Irriga, v.19, p.585-597, 2014. https://doi. org/10.15809/irriga.2014v19n4p585

Haghshenas, A.; Nasr-El-Din, H. A. Effect of dissolved solids on reuse of produced water at high temperature in hydraulic fracturing jobs. Journal of Natural Gas Science and Engineering, v.21, p.316-325, 2014. https://doi.org/10.1016/j.jngse.2014.08.013

Mantovani, E. C. AVALIA. Manual do usuário. Viçosa: DEA/UFV PNP\&D/Café EMBRAPA. 2002. 100p.

Meneses, A. C. M. A. de; ; Weber, O. B.; Crisostomo, L. A.; Andrade, D. J. Biological soil attributes in oilseed crops irrigated with oilfield produced water in the semi-arid region. Revista Ciência Agronômica, v.48, p.231-241. 2017. https://doi. org/10.5935/1806-6690.20170027

Merriam, J. L.; Keller, J. Farm irrigation system evaluation: A guide for management. Logan: Utah State University, 1978. 271p. 
Munirasu, S.; Haija, M. A.; Banat, F. Use of membrane technology for oil field and refinery produced water treatment: A review. Process Safety and Environmental Protection, v.100, p.183-202, 2016. https://doi.org/10.1016/j.psep.2016.01.010

Nakayama, F. S; Boman, B. J.; Pitts, D. Maintenance. In: Lamm, F. R.; Ayars, J. E.; Nakayama, F. S. (eds.). Microirrigation for crop production: Design, operation, and management. Amsterdam: Elsevier, 2006. Cap.11, p.389-430. https://doi.org/10.1016/ S0167-4137(07)80014-X

Pica, N. E.; Carlson, K.; Steiner, J. J.; Waskom, R. Produced water reuse for irrigation of nonfood biofuel crops: Effects on switchgrass and rapeseed germination, physiology and biomass yield. Industrial Crops and Products, v.100, p.65-76, 2017. https://doi.org/10.1016/j.indcrop.2017.02.011

Puig-Bargués, J.; Arbat, G.; Elbana, M.; Duran-Ros, M.; Barragán, J.; Ramírez de Cartagena, F.; Lamm, F. R. Effect of flushing frequency on emitter clogging in microirrigation with effluents. Agricultural Water Management, v.97, p.883-891, 2010. https:// doi.org/10.1016/j.agwat.2010.01.019

Rowan, M.; Mancl, K. M.; Tuovinen, O. H. Evaluation of drip irrigation emitters distributing primary and secondary wastewater effluents. Irrigation \& Drainage Systems Engineering, v.2, p.1-7, 2013. https://doi.org/10.4172/2168-9768.1000111
Silva, K. B. da; Batista, R. O.; Mesquita, F. de O.; Coelho, D. da C. L.; Santos, W. de O. Empirical models for performance of drippers applying cashew nutprocessing waste water. Revista Caatinga, v.29, p.405-414, 2016. https://doi.org/10.1590/198321252016v29n217rc

Silva, P. F.; Matos, R. M.; Lima, S. C.; Dantas Neto, J.; Lima, V. L. A. Obstrução e uniformidade em sistemas de irrigação por gotejamento aplicando águas residuais tratadas. Revista Ceres, v.64, p.344-350, 2017.

Sousa, A. F.; Crisostomo, L. A.; Weber, O. B.; Escobar, M. E. O.; Oliveira, T. S. de. Nutrient content in sunflowers irrigated with oil exploration water. Revista Caatinga, v.29, p.94-100, 2016. https://doi.org/10.1590/1983-21252016v29n111rc

Vale, H. S. M.; Costa, D. de O. C; Batista, R. O. B.; Coelho, D. da C. L.; Feitosa, A. P. Hydraulic performance of drippers applying sanitary landfill leachate diluted in water. Revista Caatinga, v.31, p.987-996, 2018. https://doi.org/10.1590/1983$21252018 \mathrm{v} 31 \mathrm{n} 422 \mathrm{rc}$

Weber, O. B.; Crisóstomo, L. A.; Miranda, F. B. de; Sousa, A. F.; Mesquita, A. L. M.; Cabral, J. E. de O. Production of ornamental sunflower irrigated with oilfield produced water in the Brazilian semiarid region. Pesquisa Agropecuária Brasileira, v.52, p.443454, 2017. https://doi.org/10.1590/s0100-204x2017000600008 